\title{
The antisense 5 ' end of the V2 gene confers enhanced resistance against the monopartite begomovirus cotton leaf curl Kokhran virus-Burewala strain
}

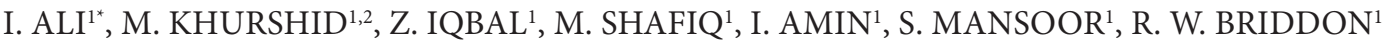

\begin{abstract}
${ }^{1}$ Agricultural Biotechnology Division, National Institute for Biotechnology and Genetic Engineering, P. O. Box 577, Jhang road, Faisalabad, Pakistan; ${ }^{2}$ Institute of Biochemistry and Biotechnology, University of the Punjab, Lahore
\end{abstract}

Received March 20, 2018; revised June 28, 2018; accepted January 03, 2019

\begin{abstract}
Summary. - Whitefly-transmitted viruses of the genus Begomovirus (the family Geminiviridae) have become a limiting factor for agricultural productivity in many warmer parts of the world. The economies of Pakistan and India have, since the early 1990s, suffered losses due to cotton leaf curl disease (CLCuD). The disease is caused by begomoviruses, the most important of which at this time is cotton leaf curl Kokhran virus strain Burewala (CLCuKoV-Bu), and a disease-specific betasatellite, cotton leaf curl Multan betasatellite (CLCuMuB). Efforts to minimize losses due to CLCuD rely mainly on the use of insecticides to kill the whitefly vector; no resistant cotton varieties are currently commercially available. The study described here has investigated RNA interference technology for its potential to yield resistance against CLCuKoV-Bu and three other begomoviruses; CLCuKoV, tomato leaf curl New Delhi virus (ToLCNDV) and Pedilanthus leaf curl virus (PeLCV). Three fragments of the virion-sense V2 gene of CLCuKoV-Bu were transformed into Nicotiana benthamiana in antisense orientation and transgenic lines expressing virus-specific short RNAs were assessed for their ability to yield resistance. Only $\mathrm{CLCuKoV}$-Bu with the V2 sequence closest to the promoter was resistant. Inoculation of CLCuKoV-Bu with $\mathrm{CLCuMuB}$ into transgenic plants did not significantly affect the outcome, although viral DNA was detected in number of plants, suggesting that the betasatellite may impair RNAi resistance. Overall the results indicate that targeting the 5 ' end of $\mathrm{V} 2$ gene using antisense-RNA has the potential to deliver resistance against begomoviruses and that RNAi-based resistance imparts some degree of resistance to heterologous viruses.
\end{abstract}

Keywords: geminivirus; begomovirus; RNAi; resistance; CLCuKoV-Burewala; CLCuMuB

\section{Introduction}

Cotton and cotton products are a major source of foreign exchange earnings for Pakistan. However, cotton production

\footnotetext{
"Present address: Centre of Agricultural Biochemistry and Biotechnology, University of Agriculture, Faisalabad, Pakistan. E-mail: irfan.nibge@gmail.com; phone: +92-1-9200161.

Abbreviations: $\mathrm{CLCuD}=$ cotton leaf curl disease; $\mathrm{CLCuKoV}=$ cotton leaf curl Kokhran virus; CLCuKoV-Bu = cotton leaf curl Kokhran virus strain Burewala; CLCuMuB = CLCuD-Multan betasatellite; $\mathrm{CLCuMuV}=\mathrm{CLCu}$ Multan virus; $\mathrm{dpi}=$ days postinoculation; IR = intergenic region; PeLCV = Pedilanthus leaf curl virus; PTGS = post-transcriptional gene silencing; Rep = replication-associated protein; TGS = transcriptional gene silencing; ToLCNDV = tomato leaf curl New Delhi virus; TrAP = transcription-activator protein
}

has been severely compromised since the early 1990s due to cotton leaf curl disease (CLCuD). CLCuD is a problem for cotton productivity in Pakistan, India and has spread also to China (Briddon and Markham, 2000; Cai et al., 2010; Zhou et al., 1998). CLCuD is caused by single-stranded DNA viruses of the genus Begomovirus (the family Geminiviridae) which are exclusively transmitted by the whitefly Bemisia tabaci (Briddon and Markham, 2000).

The genomes of begomoviruses consist of either two $\sim 2800$ nucleotides (nt) long components, known as DNA A and DNA B, or one component, a homolog of the DNA A of bipartite begomoviruses. Genes are encoded bi-directionally and separated by an $200 \mathrm{nt}$ long intergenic region (IR). Two genes are encoded by the genomes of monopartite begomoviruses (or the DNA A of bipartite begomoviruses) 
on the virion-sense strand. These encode the (A)V2 protein (involved in virus movement in plants and suppression of host defense) and the coat protein (involved in genome packaging, insect transmission and systemic spread in plants) (Hanley-Bowdoin et al., 2013; Rojas et al., 2001). Four genes are encoded on the complementary-sense strand which encode the transcription-activator protein (TrAP), the replication-enhancer protein which is involved in virus replication, the replication-associated protein (Rep) and (A)C4 protein (which can be involved in overcoming the host defenses and act as pathogenicity determinant) (Hanley-Bowdoin et al., 2013; Rojas et al., 2001). Two genes are encoded by the DNA B component, the nuclear shuttle protein in the virion-sense and the movement protein in the complementary-sense, which are involved in cell-to-cell and systemic movement (Noueiry et al., 1994).

In the Old World, a majority of begomoviruses are monopartite and associated with single-stranded DNA satellites, known as betasatellites, belonging to the Betasatellite genus (the family Tolecusatellitidae) (Adams et al., 2017; Briddon et al., 2004, 2008). Betasatellites encode a single protein, $\beta \mathrm{C} 1$, which is a dominant pathogenicity determinant and may be involved in virus movement in plants and in overcoming plant host defenses (Hanley-Bowdoin et al., 2013; Rojas et al., 2001; Zhou, 2013).

In the 1990s, five distinct species of begomoviruses were reported to be involved in the spread of CLCuD in Pakistan and northwestern India, the most important of which were cotton leaf curl Multan virus (CLCuMuV) and cotton leaf curl Kokhran virus (CLCuKoV), in association with a disease-specific betasatellite, cotton leaf curl Multan betasatellite (CLCuMuB; (Sattar et al., 2013)). Losses in cotton production persisted until the late 1990s when the introduction of resistant cotton varieties virtually eradicated the disease. Unfortunately, CLCuD symptoms in cotton reappeared in Pakistan in 2001 and the disease rapidly spread across most of Pakistan and northwestern India (Mansoor et al., 2003). Resistance breaking in cotton was shown to be associated with recombinant strain of $\mathrm{CLCuKoV}$, the Burewala strain (CLCuKoV-Bu), which lacks an intact gene encoding TrAP, and a recombinant strain of CLCuMuB (Amin et al., 2006; Amrao et al., 2010). At this time CLCuD is endemic in Pakistan and northwestern India with no commercially available cotton varieties having resistance to the virus complex that causes the disease (Sattar et al., 2013; Zubair et al., 2017).

Begomoviruses have proven difficult to control by conventional means such as the use of insecticides, agricultural management practices, and the production of resistant plant varieties by conventional breeding approaches (Iqbal et al., 2016). Transgenic approaches to obtain resistance to begomoviruses would appear to provide a possible answer to this problem. Among the available transgenic strategies, those based on RNA interference (RNAi) have been investigated most widely (Ilyas et al., 2010; Noris et al., 2004; Shepherd et al., 2009; Vanderschuren et al., 2007b).

RNAi (also referred as gene silencing) is a widely conserved process that has a role in many cellular mechanisms including host defense against pathogens, regulation of gene expression, de novo DNA methylation and chromatin remodeling (Dalakouras and Wassenegger, 2013). Characteristically RNAi involves the processing of large double-stranded RNAs into 21-24 nt small interfering RNAs (siRNAs). RNAi occurs at both the transcriptional and post-transcriptional levels. Post-transcriptional gene silencing (PTGS) acts on target RNAs, including messenger RNAs and the genomes of RNA viruses, resulting in their degradation. Transcriptional gene silencing (TGS) results from the de novo methylation of promoter sequences that may induce chromatin modifications. TGS plays a part in the maintenance of genome integrity by preventing centromeric and telomeric rearrangements, as well as by suppressing the activity of transposons and other invasive DNAs such as DNA viruses (Pumplin and Voinnet, 2013).

The (A)V2 gene has structural and positional conservation across most begomoviruses native to the Old World. The (A) V2 protein has a role in virus movement, suppression of host defense, virus accumulation and may be a symptom determinant (Iqbal et al., 2012; Mubin et al., 2007; Rojas et al., 2001). Several studies have investigated the transgenic expression of begomovirus (A)V2 gene sequences as a means of obtaining resistance to begomoviruses (Ammara et al., 2015; Mubin et al., 2007; Yasmeen et al., 2016). The study described here was designed to investigate RNAi-based resistance against $\mathrm{CLCuKoV}$-Bu by targeting the V2 gene. Three regions (N-terminal, middle region and C-terminal) of the V2 gene were used to produce anti-sense RNA constructs to investigate their ability to provide resistance in transgenic $N$. benthamiana plants and determine the most effective sequences for delivering resistance.

\section{Materials and Methods}

Production of antisense RNA constructs. Three pairs of oligonucleotide primers (V2NF/V2NR, V2MF/V2MR and V2CF/V2CR (Supplementary Table 1)) were designed to amplify the N-terminal, middle and C-terminal part of almost same size fragments of the V2 gene of CLCuKoV-Bu (AM774301) (Amrao et al., 2010). The restriction sites EcoRI and HindIII (Thermo Fisher Scientific, USA) were included in the primer sequences to allow directional cloning. The fragments were individually cloned, in antisense orientation, under the $35 \mathrm{~S}$ promoter of cauliflower mosaic virus in the expression vector pJIT163 (Guerineau and Mullineaux, 1993) to yield constructs BV2 ${ }^{\mathrm{N},} \mathrm{BV} 2^{\mathrm{M}}$ and $\mathrm{BV} 2^{\mathrm{C}}$. The $\mathrm{pJIT} 163$ expression cassettes were then cloned as KpnI/XhoI (Thermo Fisher Scientific) fragments into the binary vector pGreen0029 (Hellens et al., 2000). 
Plant transformation and plant inoculation. N. benthamiana was transformed using the leaf disc method (Horsch et al., 1985). Primary transformed plants $\left(\mathrm{T}_{0}\right)$ were confirmed to contain the transgene by PCR using specific primers (V2NF/V2NR, V2MF/ V2MR and V2CF/V2CR (Supplementary Table 1)) to amplify the fragments of the V2 gene. The plants were then self-pollinated and resulting seeds were collected and germinated on basal MS media (Sigma-Aldrich, Germany) containing kanamycin. Resultant plants were transferred to soil and acclimatized in an insectfree glasshouse at $25^{\circ} \mathrm{C}$ with supplementary lighting for 16 hours daylight. Transgenic plants were challenged with CLCuKoV-Bu (AM421522), CLCuKoV (AJ496286), CLCuMuB (AJ298903), PeLCV (AM948961) and ToLCNDV (DNA A [U15015] and DNA B [U15017]) by Agrobacterium-mediated inoculation as described previously (Hussain et al., 2007).

Extraction of total nucleic acids from plants and detection of viral DNA. Total genomic DNA was extracted from leaf tissue using the CTAB method (Doyle and Doyle, 1990). For PCR-mediated diagnostics of viruses, we have used primer pairs IRVF/IRVR for CLCuKoV, CLCKV2F/CLCKV2R for CLCuKoV-Bu, PedLCVV2F/ PedLCVV2R for PeLCV and ToLCNDV2F/ToLCNDV2R for ToLCNDV (Supplementary Table 1). For Southern blot analysis, $10 \mu \mathrm{g}$ of total DNA was separated on $1 \%$ agarose gel in $0.5 x$ TAE buffer and transferred to nylon membrane (Hybond N+, GE Healthcare, USA) (Sambrook et al., 1989). Membranes were hybridized with viral DNA fragments labeled with DIG using specific primers (IRVF/ IRVR for CLCuKoV, CLCKV2F/CLCKV2R for CLCuKoV-Bu, PedLCVV2F/PedLCVV2R for PeLCV and ToLCNDV2F/ToLCNDV2R for ToLCNDV) (Supplementary Table 1) and a PCR DIG probe synthesis kit (Roche, Germany) and detected with a DIG luminescent detection kit (Roche) according to manufacturer's instructions.

Detection of small RNAs. Total genomic RNA was isolated from plant tissues using Trizol reagent (Invitrogen, USA) following the manufacturer's instructions and stored at $-80^{\circ} \mathrm{C}$. Transgene derived small RNAs were detected as described previously (Akbergenov $e t$ al., 2006). Small RNAs were transferred to Hybond $N+$ membrane in $1 \mathrm{x}$ TBE using an electroblotter (Transphor unit TE52, Hoefer Inc, USA) at $4^{\circ} \mathrm{C}$ and run at $10 \mathrm{~V}$ for $16-20 \mathrm{~h}$. The RNAs were fixed to the membrane by UV crosslinking and stored dry at $4^{\circ} \mathrm{C}$ until use. The membrane was first incubated in $5 \mathrm{ml}$ Ultra-hyb-oligo buffer (Thermo Fisher Scientific) in a hybridization oven for $2 \mathrm{~h}$ at $45^{\circ} \mathrm{C}$. DIG labelled specific probes were produced using specific primers (NterS/NterAS, MPorS/MPorAS and CterS/CterAS) (Supplementary Table 1) and the DIG PCR labelling kit.

Quantification of viral components by quantitative real-time PCR. The quantity and quality of extracted genomic DNA was assessed (NanoDrop ND-1000 spectrophotometer, Thermo Fisher Scientific) and the concentration was adjusted to $10 \mathrm{ng} / \mu \mathrm{l}$. Reactions were conducted in an iCycler Thermal Cycler with iQ5 Multicolor Real-Time PCR detection system (Bio Rad, USA). Reactions consisted of a total volume of $25 \mu \mathrm{l}$ with $12.5 \mu \mathrm{l}$ of SYBR Green super mix (Thermo Fisher Scientific), $0.25 \mu$ of each primer (2.5 pmol/l each), $2.5 \mu \mathrm{l}$ DNA (25 ng), and $9.5 \mu \mathrm{l}$ sterile distilled water. The performed cycle profile was: $94^{\circ} \mathrm{C}$ for $10 \mathrm{~min}$ followed by 40 cycles of $30 \mathrm{~s}$ at $94^{\circ} \mathrm{C}, 30 \mathrm{~s}$ at $57^{\circ} \mathrm{C}$ and $30 \mathrm{~s}$ at $72^{\circ} \mathrm{C}$. Reactions were performed in 96 well microtitre plates (Bio-Rad, USA). At the end of each run a melt curve analysis was performed from $57^{\circ} \mathrm{C}$ to $95^{\circ} \mathrm{C}$, with an increment of $0.5^{\circ} \mathrm{C}$ at $10 \mathrm{~s}$ intervals. All PCR reactions were performed in triplicates on 96 well-plates with all necessary controls for producing standard curves, as described earlier (Shafiq et al., 2017). Statistical analysis of the quantitative real-time PCR (qRT-PCR) results (two tailed $t$ test) were conducted using Excel (Microsoft Corp., USA).

\section{Results}

\section{Analysis of transgenic plants}

Transgenic plants produced from all independent transformation events were confirmed by growing on media containing kanamycin and by PCR. The $\mathrm{T}_{1}$ generation plants were found to be segregating and showed differing levels of tolerance on kanamycin. These kanamycin resistant plants were further evaluated for the presence of the transgenes by PCR with 35 S promoter (P35F/P35R) as well as gene specific primers. The PCR showed $64.28 \%$ plants in line $1,21.43 \%$ in line 2 and $63.63 \%$ in line 3 of $B V 2^{\mathrm{N}}$ plants to harbor the transgene in the $\mathrm{T}_{1}$ generation. For $\mathrm{BV} 2^{\mathrm{M}}$ plants, $75 \%$ in line $1,30 \%$ in line 2 and $77.7 \%$ in line 3 were found to harbor the transgene. Whereas, $72.22 \%, 73.33 \%$ and $36.84 \%$ of plants were confirmed as transgenic for BV2 ${ }^{\mathrm{C}}$ lines 1,2 and 3 , respectively.

In the $\mathrm{T}_{2}$ generation, all lines were segregating but with fewer kanamycin susceptible plants than in the $\mathrm{T}_{1}$ generation. The kanamycin resistant plants were also subjected to PCR confirmation and, except for one plant for line 1 of $B V 2^{\mathrm{N}}$, all plants harbored the respective transgene (Supplementary Table 2).

Plants of the $\mathrm{T}_{3}$ generation were used for infectivity analysis after germination on kanamycin containing medium and PCR-mediated confirmation. Plants in the T3 generation were homozygous and no segregation could be detected. These homozygous lines were subjected to transgene derived small RNA analysis (Supplementary Fig. 2). Among the tested transgenic lines, plants of line 2 of $B V 2^{\mathrm{N}}$, line 2 of $\mathrm{BV} 2^{\mathrm{M}}$ and line 3 of $\mathrm{BV} 2^{\mathrm{C}}$ produced detectable levels of transgene derived small RNAs and the seeds of these plants were used further for infectivity analysis.

\section{Evaluation of resistance to $\mathrm{CLCuKoV}-\mathrm{Bu}$ in transgenic} N. benthamiana

Wild type (non-transgenic) plants of $N$. benthamiana inoculated with CLCuKoV-Bu showed vein swelling, leaf 
(a)

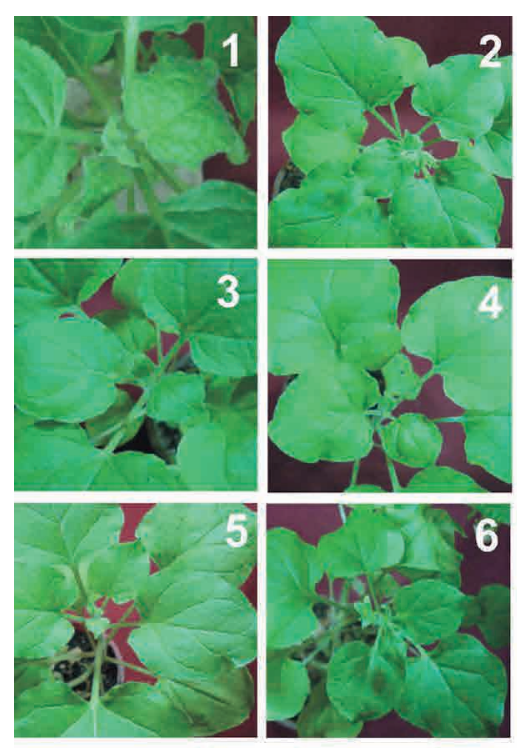

(d)
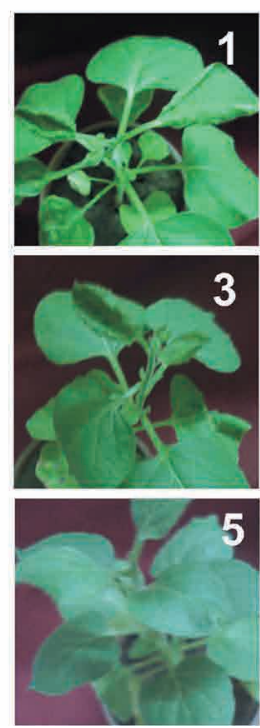

(b)
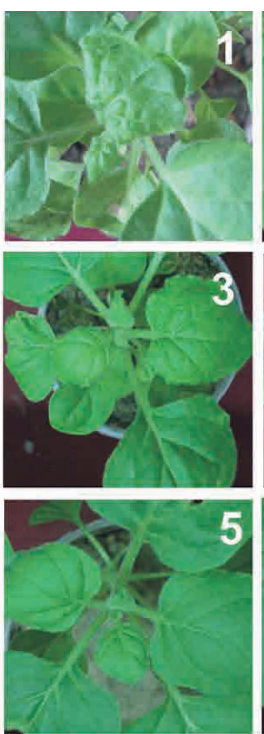
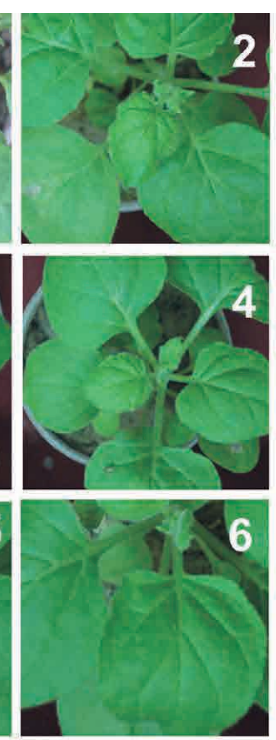

(e)
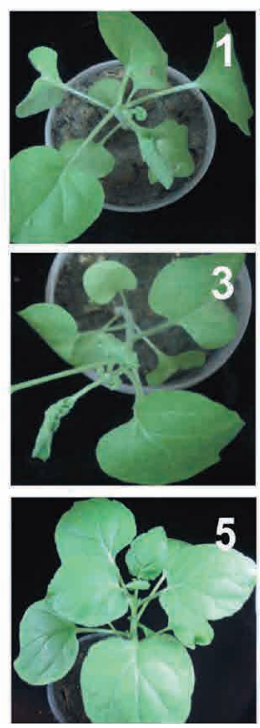

(c)
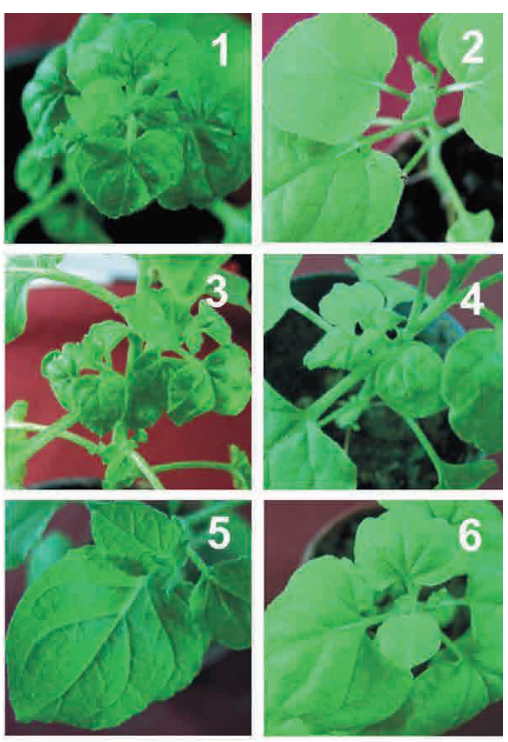
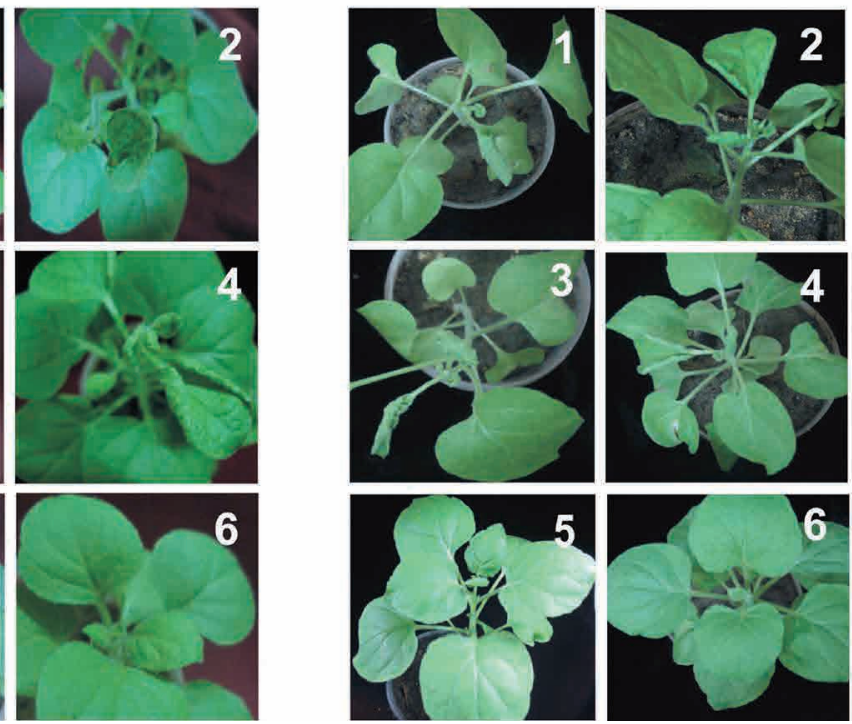

Fig. 1

Symptoms exhibited by transgenic $N$. benthamiana plants after inoculation with begomoviruses

Transgenic plants harboring the $\mathrm{BV} 2^{\mathrm{N}}, \mathrm{BV} 2^{\mathrm{M}}$ and $\mathrm{BV} 2^{\mathrm{C}}$ constructs were inoculated with (a) the CLCuKoV-Bu (2, 3 and 4$),(\mathbf{b}) \mathrm{CLCuKoV}-\mathrm{Bu}$ and CLCuMuB (2, 3 and 4), (c) CLCuKoV (2, 3 and 4), (d) PedLCuV (2, 3 and 4) and (e) ToLCNDV (2, 3 and 4). Non-transgenic plants inoculated with (a) CLCuKoV-Bu (1), (b) CLCuKoV-Bu and CLCuMuB (1), (c) CLCuKoV (1), (d) PedLCuV (1), (e) ToLCNDV (1) are shown for comparison. 5 and 6 show non-inoculated, non-transgenic plants and mock inoculated plants, respectively, in each case. Photographs were taken at $28 \mathrm{dpi}$.

curling, vein yellowing and a reduction in leaf size symptoms at 9 days post-inoculation (dpi) and by $28 \mathrm{dpi}$ all plants were symptomatic with leaf curling, prominent vein thickening, and a reduction in leaf size (Fig. 1a,1) resulting in stunted plants. Viral DNA was detected in young, newly developing leaves by PCR-mediated diagnostics and by Southern blot hybridization (Table 2; Supplementary Fig. 1a). In contrast, inoculation of transgenic $N$. benthamiana plants harboring the $\mathrm{BV} 2^{\mathrm{N}}$ construct did not result in symptoms, even at 28 dpi (Fig. 1a,2). PCR-mediated diagnostics, however, showed the presence of the virus in one plant of the 20 inoculated (Table 2) but no viral DNA was detected by Southern blot 
Table 1. Infectivity of inoculated homologous and heterologous begomoviruses in transgenic N. benthamiana plants

\begin{tabular}{|c|c|c|c|c|c|c|c|c|c|c|}
\hline \multirow{3}{*}{ Plant } & \multicolumn{10}{|c|}{ Infectivity (plants symptomatic/plants inolculated) } \\
\hline & \multicolumn{2}{|c|}{ CLCuKoV-Bu } & \multicolumn{2}{|c|}{ CLCuKoV-Bu \& CLCuMuB } & \multicolumn{2}{|c|}{ CLCuKoV } & \multicolumn{2}{|c|}{ PeLCV } & \multicolumn{2}{|c|}{ ToLCNDV } \\
\hline & $15 \mathrm{dpi}$ & $28 \mathrm{dpi}$ & 15dpi & $28 \mathrm{dpi}$ & $15 \mathrm{dpi}$ & $28 \mathrm{dpi}$ & 15 dpi & $28 \mathrm{dpi}$ & $15 \mathrm{dpi}$ & $28 \mathrm{dpi}$ \\
\hline N. $b$. & $19 / 20$ & $20 / 20$ & $18 / 20$ & $20 / 20$ & $20 / 10$ & $20 / 20$ & $20 / 20$ & $20 / 20$ & $19 / 20$ & $20 / 20$ \\
\hline $\mathrm{BV} 2^{\mathrm{N}}$ & $0 / 20$ & $0 / 20$ & $0 / 20$ & $0 / 20$ & $0 / 20$ & $0 / 20$ & $18 / 20$ & $20 / 20$ & $16 / 20$ & $20 / 20$ \\
\hline $\mathrm{BV} 2^{\mathrm{M}}$ & $12 / 20$ & $0 / 20$ & $12 / 20$ & $0 / 20$ & $0 / 20$ & $18 / 20$ & $12 / 20$ & $20 / 20$ & $9 / 20$ & $20 / 20$ \\
\hline $\mathrm{BV} 2^{\mathrm{C}}$ & $7 / 20$ & $0 / 20$ & $7 / 20$ & $0 / 20$ & $0 / 20$ & $1 / 20$ & $13 / 20$ & $20 / 20$ & $6 / 20$ & $20 / 20$ \\
\hline$N . b^{*}$ & $0 / 20$ & $0 / 20$ & $0 / 20$ & $0 / 20$ & $0 / 20$ & $0 / 20$ & $0 / 20$ & $0 / 20$ & $0 / 20$ & $0 / 20$ \\
\hline$N . b^{*}$ & $0 / 10$ & $0 / 10$ & $0 / 10$ & $0 / 10$ & $0 / 10$ & $0 / 10$ & $0 / 10$ & $0 / 10$ & $0 / 10$ & $0 / 10$ \\
\hline
\end{tabular}

"Non-transgenic N. benthamiana plants inoculated with Agrobacterium cultures harboring pGreen0029." Non-inoculated plants.

Table 2. Detection of inoculated begomoviruses in transgenic $N$. benthamiana plants

\begin{tabular}{|c|c|c|c|c|c|c|c|c|c|c|c|c|}
\hline \multirow[b]{3}{*}{ Plant } & \multicolumn{12}{|c|}{ Plants positive/plants inolculated } \\
\hline & \multicolumn{6}{|c|}{ PCR } & \multicolumn{6}{|c|}{ Southern blot } \\
\hline & $\begin{array}{l}\tilde{0} \\
0 \\
0 \\
0 \\
3 \\
0 \\
0 \\
0 \\
0\end{array}$ & 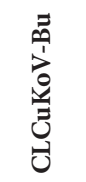 & $\sum_{J}^{ٍ}$ & $\begin{array}{l}\overrightarrow{0} \\
0 \\
3 \\
3 \\
0 \\
0\end{array}$ & $\begin{array}{l}\overrightarrow{0} \\
0 \\
0\end{array}$ & 完 & $\begin{array}{l}\overrightarrow{0} \\
0 \\
0 \\
0 \\
0 \\
3 \\
0 \\
0 \\
0\end{array}$ & 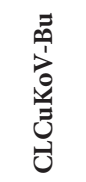 & $\sum_{\mathcal{J}}^{\bullet}$ & $\begin{array}{l}3 \\
0 \\
3 \\
3 \\
0 \\
0\end{array}$ & 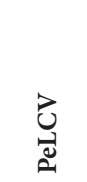 & 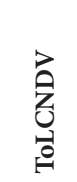 \\
\hline N.b. & $20 / 20$ & $20 / 20$ & $20 / 20$ & $18 / 20$ & $20 / 20$ & $20 / 20$ & ++++ & ++++ & +++ & ++++ & ++++ & ++++ \\
\hline $\mathrm{BV} 2^{\mathrm{N}}$ & $1 / 20$ & $7 / 20$ & $0 / 20$ & $19 / 20$ & $20 / 20$ & $20 / 20$ & - & + & - & + & ++++ & ++++ \\
\hline $\mathrm{BV} 2^{\mathrm{M}}$ & $17 / 20$ & $16 / 20$ & $15 / 20$ & $20 / 20$ & $20 / 20$ & $20 / 20$ & + & + & - & ++ & +++ & +++ \\
\hline $\mathrm{BV} 2^{\mathrm{C}}$ & $8 / 20$ & $8 / 20$ & $3 / 20$ & $20 / 20$ & $20 / 20$ & $20 / 20$ & + & + & - & + & +++ & +++ \\
\hline$N . b^{*}$ & $0 / 20$ & $0 / 20$ & $0 / 20$ & $0 / 20$ & $0 / 20$ & $0 / 20$ & ND & ND & ND & ND & ND & ND \\
\hline N. b $b^{\#}$ & $0 / 10$ & $0 / 10$ & $0 / 10$ & $0 / 10$ & $0 / 10$ & $0 / 10$ & - & - & - & - & - & - \\
\hline
\end{tabular}

"Non-transgenic N. benthamiana plants inoculated with Agrobacterium cultures harboring pGreen0029. Non-inoculated plants. Viruses/betasatellites were detected in nucleic acids extracted from plants by PCR using specific primers (Supplementary Table 1). Southern blot hybridization results are given as strong hybridization $(++++)$ through weak hybridization $(+++)$ to no hybridization detected $(-)$. Some plants were not examined for the presence of virus by hybridization (ND).

hybridization (Supplementary Fig. 1a), indicating that viral DNA levels were below the detection threshold.

$N$. benthamiana plants harboring the $\mathrm{BV} 2^{\mathrm{M}}$ and $\mathrm{BV} 2^{\mathrm{C}}$ constructs inoculated with CLCuKoV-Bu started showing symptoms of infection between 12 and 15 dpi which subsequently became mild in newly developing leaves and ultimately the plants recovered, showing no symptoms on new growth (Fig. 1a,3 and 4; Table 1). For the BV2 ${ }^{\mathrm{M}}$ plants, viral DNA was identified in most of the asymptomatic plants by PCR analysis (17 out of 20 inoculated) but was not found in Southern blot hybridization (Table 2), suggesting the virus level was below the detection limit (Supplementary Fig. 1a). In contrast, for the $\mathrm{BV} 2^{\mathrm{C}}$ plants, PCR diagnostics showed far fewer plants ( 8 out of 20 inoculated) to contain the virus and very weak signals were found by Southern blot hybridization (Supplementary Fig. 1a). qPCR analysis showed that the titer of CLCuKoV-Bu in infected $\mathrm{BV} 2^{\mathrm{C}}$ transgenic plants was significantly higher than the titer in infected $\mathrm{BV} 2^{\mathrm{M}}$ transgenic plants. However, for $\mathrm{BV} 2^{\mathrm{N}}$ transgenic plants, virus level was below the detection limit (Supplementary Table 3).

\section{Evaluation of resistance to CLCuKoV-Bu and CLCuMuB} in transgenic N. benthamiana

Non-transgenic $N$. benthamiana plants co-inoculated with CLCuKoV-Bu and CLCuMuB developed symptoms consisting of leaf curling, vein thickening, yellowing of veins and a reduction in leaf size at 9 dpi (Fig. 1b,1). All inoculated plants developed symptoms and PCR diagnostics showed the presence of both the virus and the betasatellite in all the plants (Table 1 and 2). In contrast, inoculation of transgenic $N$. benthamiana plants harboring the $\mathrm{BV} 2^{\mathrm{N}}$ construct did not develop symptoms of infection, even at $28 \mathrm{dpi}$ (Fig. 1b,2). PCR-mediated diagnostics, however, showed the presence of the virus, but not the betasatellite, in seven plants of the 20 inoculated. Southern blot hybridization detected neither viral DNA nor betasatellite DNA (Supplementary Fig. 1a and c). 
CLCuKoV-Bu and CLCuMuB inoculated N. benthamiana plants harboring the $\mathrm{BV} 2^{\mathrm{M}}$ and $\mathrm{BV} 2^{\mathrm{C}}$ constructs developed mild leaf curl symptoms at 15 dpi that reduced gradually, and plants ultimately recovered from infection (all plants were non-symptomatic in new growth at $\sim 28$ dpi; Fig. 1b,3 and 4). For the BV2 ${ }^{\mathrm{M}}$ plants, PCR diagnostics showed the presence of the virus in 16 plants and the betasatellite in 15 (out of 20 inoculated) plants (Table 2). However, possibly very low viral DNA levels (of the linear form) but no betasatellite DNA were detected in Southern blot hybridization (Supplementary Fig. $1 \mathrm{~b}$ and c). In contrast, for the BV2 ${ }^{\mathrm{C}}$ plants, PCR diagnostics showed fewer plants ( 8 out of 20 inoculated) to contain the virus and only 3 to contain the betasatellite (Table 2). Again, possibly very low viral DNA levels (of the linear form) but no betasatellite DNA were detected in Southern blot hybridization (Supplementary Fig. 1c). qPCR analysis indicated that the titer of virus in CLCuKoV-Bu/CLCuMuB infected BV2 ${ }^{\mathrm{M}}$ transgenic plants was significantly higher than the titer of virus in $B V 2^{\mathrm{C}}$ and $\mathrm{BV} 2^{\mathrm{N}}$ transgenic plants, whereas the titer of the betasatellite was highest in $\mathrm{BV} 2^{\mathrm{C}}$ plants and the lowest in $\mathrm{BV} 2^{\mathrm{N}}$ plants (Supplementary Table 3).

\section{Evaluation of resistance to CLCuKoV in transgenic $N$. benthamiana}

All non-transgenic $N$. benthamiana plants inoculated with CLCuKoV developed leaf curling, vein thickening and leaf darkening symptoms by 24 dpi (Fig. 1c,1). Except for just one plant, which showed very mild symptoms, none of transgenic $N$. benthamiana plants harboring the $\mathrm{BV} 2^{\mathrm{N}}$ and $\mathrm{BV} 2^{\mathrm{C}}$ constructs showed symptoms of infection even at 28 dpi (Fig. 1c,2 and 4). Transgenic plants harboring BV2 ${ }^{\mathrm{M}}$ showed mild symptoms consisting of downward leaf curling by 25 dpi. By 28 dpi, most of the plants (18 out of 20) harboring $\mathrm{BV} 2^{\mathrm{M}}$ started showing symptoms of infection which were milder than non-transgenic $N$. benthamiana plants inoculated with virus (Fig. 1c,3).

PCR-mediated diagnostics for CLCuKoV showed the presence of viral DNA in newly developing leaves of all transgenic plants except one BV2 ${ }^{\mathrm{N}}$ plant (Table 2). Southern blot hybridization analysis showed low viral DNA levels in $\mathrm{BV} 2^{\mathrm{N}}$ and $\mathrm{BV} 2^{\mathrm{C}}$ plants (Supplementary Fig. 1d). In contrast, the levels of virus detected in $\mathrm{BV} 2^{\mathrm{M}}$ plants were comparable to those detected in non-transgenic $N$. benthamiana plants. In contrast to CLCuKoV-Bu inoculated plants, the qPCR analysis shows that the titer of $\mathrm{CLCuKoV}$ in $\mathrm{BV} 2^{\mathrm{C}}$ transgenic plants was significantly lower than the titer in $\mathrm{BV} 2^{\mathrm{M}}$ transgenic plants infected with CLCuKoV. However, in BV2 ${ }^{\mathrm{N}}$ transgenic plants, no virus was detected (Supplementary Table 3).

\section{Evaluation of resistance to PeLCV in transgenic N. benthamiana}

Non-transgenic N. benthamiana plants are highly susceptible to PeLCV and all plants developed leaf curling and vein darkening symptoms at $15 \mathrm{dpi}$ which increased in severity, peaking at $21 \mathrm{dpi}$ (Fig. 1d,1). Similarly, transgenic $B V 2^{\mathrm{N}}$, $\mathrm{BV} 2^{\mathrm{M}}$ and $\mathrm{BV} 2^{\mathrm{C}}$ plants exhibited symptoms at $15 \mathrm{dpi}$ that culminated at 21 dpi (Fig. 1d,2, 3 and 4).

Viral DNA was detected by diagnostic PCR in all inoculated $\mathrm{BV} 2^{\mathrm{N}}$ plants (Table 2). Initially fewer $\mathrm{BV} 2^{\mathrm{M}}$ and $\mathrm{BV} 2^{\mathrm{C}}$ plants (12/20 and 13/20, respectively) showed symptoms. Nevertheless, ultimately, all plants were symptomatic. Southern blot analysis showed $\mathrm{BV} 2^{\mathrm{M}}$ and $\mathrm{BV} 2^{\mathrm{C}}$ to contain significantly less viral DNA in young developing tissues than either inoculated $\mathrm{BV} 2^{\mathrm{N}}$ or inoculated non-transgenic plants (Supplementary Fig. 1e). The qPCR analysis indicated that the titer of PeLCV in BV2 $2^{\mathrm{N}}$ transgenic plants infected with PeLCV was significantly higher than the titer of virus in $\mathrm{BV} 2^{\mathrm{M}}$ and $\mathrm{BV} 2^{\mathrm{C}}$ transgenic plants (Supplementary Table 3 ).

\section{Evaluation of resistance to ToLCNDV in transgenic N. benthamiana}

The first symptoms of infection appeared on non-transgenic N. benthamiana plants inoculated with the DNA A and DNA B components of ToLCNDV at 14 dpi in the form of upward leaf curling, leaf yellowing, vein thickening and a reduction in leaf size (Fig. 1e,1).

Transgenic $N$. benthamiana plants harboring the $\mathrm{BV} 2^{\mathrm{N}}$ construct inoculated with ToLCNDV showed symptoms comparable to non-transgenic plants (Fig. 1e,2). However, for a few plants (4 out of 20 inoculated) the onset of symptoms was delayed by 1 to 2 days over non-transgenic plants (Table 1). Southern blot hybridization showed the accumulation of approximately the same levels of viral DNA in $B V 2^{\mathrm{N}}$ plants as detected in non-transgenic plants (Supplementary Fig. 1f).

Inoculated $\mathrm{BV} 2^{\mathrm{M}}$ and $\mathrm{BV} 2^{\mathrm{C}}$ plants responded in the same way as $B V 2^{\mathrm{N}}$ plants with some plants showing a delay in the initial appearance of symptoms by 1 to 2 days although a greater number of plants showed the delay (11 out of 20 for $\mathrm{BV} 2^{\mathrm{M}}$ and 14 out of 20 for $\mathrm{BV} 2^{\mathrm{C}}$; Table 1 ). Eventually all plants showed full symptoms of infection which were indistinguishable from the symptoms exhibited by non-transgenic plants. Southern blot analysis of $\mathrm{BV} 2^{\mathrm{M}}$ and $\mathrm{BV} 2^{\mathrm{C}}$ inoculated plants showed the accumulation of viral DNA at levels that were slightly lower than in either infected non-transgenic or $\mathrm{BV} 2^{\mathrm{N}}$ transgenic plants with the main difference being a lower level of the ssDNA form. The qPCR analysis indicated that the level ToLCNDV DNA A in ToLCNDV infected BV2 ${ }^{\mathrm{N}}$ transgenic plants was significantly higher than in $\mathrm{BV} 2^{\mathrm{M}}$ and $\mathrm{BV} 2^{\mathrm{C}}$ transgenic plants (Supplementary Table 3). 


\section{Discussion}

RNAi has been widely investigated as a means of obtaining resistance to plant pathogenic viruses (Ilyas et al., 2010; Shepherd et al., 2009; Vanderschuren et al., 2007b). Despite these successes in model plants, so far only a single RNAibased resistance against a geminivirus has been approved for cultivation; a common bean variety with resistance against bean golden mosaic virus in Brazil (Aragão and Faria, 2009; Aragão et al., 2013). The work presented here was aimed at engineering RNAi-mediated resistance against monopartite begomoviruses. Specifically, three regions of a gene were examined to determine the best sequence for resistance.

Transgenic plants harboring the $\mathrm{BV} 2^{\mathrm{N}}$ construct exhibited better resistance against the homologous virus, CLCuKoV$\mathrm{Bu}$, than the other two constructs. Geminiviruses transcribe in a bi-directional manner using promoter sequences residing in the IR (Frischmuth et al., 1991). Targeting promoter sequences by RNAi may provide an enhanced virus resistance, most likely due to TGS and DNA methylation (Vanderschuren et al., 2007a). Some success has been achieved using this approach (Pooggin et al., 2003; Wang et al., 2014; Yadav and Chattopadhyay, 2011). The better resistance yielded by the $\mathrm{N}$-terminal sequence of the $\mathrm{V} 2$ gene (construct $\mathrm{BV} 2^{\mathrm{N}}$ ) may thus be due to these sequences lying adjacent to the IR, with promoter sequences silenced by TGS due to transitive RNAi (Himber et al., 2003; Pooggin et al., 2003).

In the present study, resistance was reduced in transgenic plants when virus was co-inoculated with betasatellite. It was previously suggested that betasatellite can overcome the PTGS mediated resistance (Mubin et al., 2011; Cui et al., 2005). This is likely due to the fact that betasatellites encode a strong suppressor of both TGS and PTGS - the $\beta C 1$ protein (Li et al., 2014; Shukla et al., 2013; Yang et al., 2011b). Certainly, an effect of the betasatellite was seen here - in the best resistant line $\left(\mathrm{BV} 2^{\mathrm{N}}\right)$ viral DNA levels were raised in the presence of CLCuMuB such that they could be detected by hybridization and the virus was detected in more plants by PCR-diagnostics. Nevertheless, plants remained symptomless. This contrasts with the results of Mubin et al. (2011) where, in the presence of the betasatellite, transgenic plants harboring Rep sequences showed symptoms. This difference may indicate that V2-targeted silencing is more efficient than Rep-targeted silencing at preventing suppression of the silencing effect. Maintenance of betasatellites by begomoviruses requires both trans-replication by the helper virus-encoded Rep (Iqbal et al., 2012; Rojas et al., 2001) and trans-movement by the helper virus movement functions (which for monopartite begomoviruses include the V2 protein, CP and possibly C4) (Iqbal et al., 2012; Qazi et al., 2007). The lack of symptoms for CLCuKoV-Bu/ CLCuMuB inoculated transgenic plants here may be due to suppression of expression of the V2 protein, which is re- quired for symptoms even in the presence of the dominant symptom determinant encoded by $\beta C 1$ (Iqbal et al., 2012). Alternatively, slowing down the spread of virus in plants may be due to the V2-mediated resistance, allowing transgenemediated silencing to more effectively counter the virus. In Rep silenced plants replication is slowed (but apparently not abolished), possibly allowing the virus to spread and induce symptoms.

Across the three regions of V2 sequence used, the $\mathrm{CLCuKoV}$ clone shows only one nucleotide change (in the $\mathrm{N}$-terminal V2 fragment) with respect to CLCuKoV-Bu; the sequences of the middle and C-terminal fragments are identical (Supplementary Fig. 3). Despite this the resistance to $\mathrm{CLCuKoV}$ is poorer than to $\mathrm{CLCuKoV}-\mathrm{Bu}$. Overall more transgenic plants are infected by CLCuKoV (as judged by PCR diagnostics), virus levels in plants were possibly higher, for the $\mathrm{BV} 2^{\mathrm{C}}$ construct, and plants did not recover. Since these differences in responses to infection by CLCuKoV-Bu and CLCuKoV cannot be attributed to sequence differences they must be due to the viruses concerned. No work has been conducted to examine the relative potencies of homologous suppressor from different geminiviruses, or the relative abilities of different geminiviruses to replicate and spread in plants. The poorer response of transgenic plants to CLCuKoV, in comparison to CLCuKoV-Bu, may thus be due to CLCu$\mathrm{KoV}$ encoding more effective suppressors, which counter the resistance, or the virus is better able to replicate in, and/ or spread throughout plants more efficiently - thereby possibly being less affected by the transgene mediated silencing effect. This is an important question, which will need to be addressed in the future if broad spectrum resistance (resistance from one construct against a number of different viruses) is to be achieved.

There is one significant difference between these two viruses which might be responsible for the poorer resistance to $\mathrm{CLCuKoV}$ than $\mathrm{CLCuKoV}-\mathrm{Bu}$. CLCuKoV-Bu associated with resistance breaking in cotton across Pakistan and northwestern India is the only begomovirus known to lack an intact TrAP-encoding gene (Amrao et al., 2010) that has been found to be important in maintenance of betasatellite (Iqbal et al., 2017). Although one might think that a virus lacking a full TrAP might be impaired, CLCuKoV-Bu is nevertheless infectious (Amrao et al., 2010; Rajagopalan et al., 2012; Zaffalon et al., 2012) and present across a large area of southern Asia (Amrao et al., 2010; Rajagopalan et al., 2012; Zaffalon et al., 2012). Although the resistance to PeLCV provided by the three constructs was very poor, $\mathrm{BV} 2^{\mathrm{M}}$ and $\mathrm{BV} 2^{\mathrm{C}}$ appeared to provide marginally better resistance than the overall best construct $B V 2^{\mathrm{N}}$. Comparisons of the sequence of PeLCV homologous to the three transgenes (Supplementary Fig. 3), showed the N-terminal fragment to have 13 mismatches, whereas the middle and C-terminal fragments have 3 and 4 respectively. This result is thus con- 
sistent with the idea that RNAi is a homology-dependent phenomenon (Baulcombe, 1996; Chellappan et al., 2004). The same is also the case for ToLCNDV.

For a number of the transgenic plants inoculated as part of this study, there were initial symptoms which gradually declined with, ultimately, new growth on plants showing no symptoms. This is a phenomenon known as recovery and is attributed to a build-up of siRNA (Chellappan et al., 2004; Yang et al., 2011a). The recovery seen thus likely indicates that, although the virus is initially able to replicate to levels which induce symptoms in the plant, ultimately the transgene derived siRNAs are able to reduce virus levels such that they are no longer able to affect plant growth and development. An analysis of the viral siRNA produced in response to infection in tomato and $N$. benthamiana by the monopartite begomovirus tomato yellow leaf curl China virus showed the distribution of siRNA to be non-uniform, with a greater proportion of the siRNA produced against the region of the genome containing the V2 gene (Yang et al., 2011a). The analyses indicated that the greater proportion of siRNA in this region was due to the higher expression levels (higher levels of transcription) across this region, rather than due to transcripts in this region having more secondary structures (leading to hairpin structures [dsRNA]) which might act as substrate for processing into siRNA. However, what is unclear from the work of Yang et al. (2011a) is whether, with more siRNA targeting the V2 region during infection, this makes the V2 sequences a more or less effective target for RNAi-mediated engineered resistance. Certainly, the results obtained in the study presented here suggest that the V2 sequence, and specifically the $\mathrm{N}$-terminal end of V2, is a good sequence for delivering resistance.

The question of which region of the genome of monopartite begomoviruses makes the best target for resistance has been addressed previously (Lin et al., 2012). A not dissimilar study of the monopartite begomovirus CLCuMuV also concluded that the sequences of the overlapping Rep and TrAP genes formed the best target for resistance (Mubin et al., 2011). Since these two studies and that of Yang et al. (2011) used distinct viruses, it is not possible to draw definitive conclusions. Such studies would need to be done using one virus to assess whether the region of the genome that induces the greatest number of siRNA during a normal infection is also the best target for RNAi-mediated resistance. This is something that will need to be addressed in the future, so that the best RNAi-mediated resistance can be achieved.

Acknowledgments. IrA, ZI and MS were supported by indigenous Ph.D fellowships from the Higher Education Commission (HEC), Government of Pakistan. RWB was supported by the HEC under the "Foreign Faculty Hiring Program". The research was additionally supported by a project from the Ministry of Science and Technology, Government of Pakistan.
Supplementary information is available in the online version of paper.

\section{References}

Adams MJ, Lefkowitz EJ, King AMQ, Harrach B, Harrison RL, Knowles NJ, Kropinski AM, Krupovic M, Kuhn JH, Mushegian AR, Nibert M, Sabanadzovic S, Sanfaçon H, Siddell SG, Simmonds P, Varsani A, Zerbini FM, Gorbalenya AE, Davison AJ (2017): Changes to Taxonomy and the International Code of Virus Classification and Nomenclature ratified by the International Committee on Taxonomy of Viruses. Arch. Virol. 162, 2505-2538. https://doi.org/10.1007/s00705-017-3358-5

Akbergenov R, Si-Ammour A, Blevins T, Amin I, Kutter C, Vanderschuren H, Zhang P, Gruissem W, Meins F, Jr., Hohn T, Pooggin MM (2006): Molecular characterization of geminivirus-derived small RNAs in different plant species. Nucleic Acids Res. 34, 462-471. https://doi. org/10.1093/nar/gkj447

Amin I, Mansoor S, Amrao L, Hussain M, Irum S, Zafar Y, Bull SE, Briddon RW (2006): Mobilisation into cotton and spread of a recombinant cotton leaf curl disease satellite. Arch. Virol. 151, 2055-2065. https://doi.org/10.1007/ s00705-006-0773-4

Ammara U, Mansoor S, Saeed M, Amin I, Briddon RW, Al-Sadi AM (2015): RNA interference-based resistance in transgenic tomato plants against Tomato yellow leaf curl virus-Oman (TYLCV-OM) and its associated betasatellite. Virol. J. 12, 38. Amrao L, Amin I, Shahid S, Briddon RW, Mansoor S (2010): Cotton leaf curl disease in resistant cotton is associated with a single begomovirus that lacks an intact transcriptional activator protein. Virus Res. 152, 153-163. https://doi.org/10.1016/j.virusres.2010.06.019

Aragão FJL, Faria JC (2009): First transgenic geminivirus-resistant plant in the field. Nat. Biotech. 27, 1086-1088. https://doi. org/10.1038/nbt1209-1086

Aragão FJL, Nogueira EOPL, Tinoco MLP, Faria JC (2013): Molecular characterization of the first commercial transgenic common bean immune to the Bean golden mosaic virus. J. Biotechnol. 166, 42-50. https://doi.org/10.1016/j.jbiotec.2013.04.009

Baulcombe DC (1996): RNA as a target and an initiator of posttranscriptional gene silencing in trangenic plants. Plant Mol. Biol. 32, 79-88. https://doi.org/10.1007/BF00039378

Briddon RW, Brown JK, Moriones E, Stanley J, Zerbini M, Zhou X, Fauquet CM (2008): Recommendations for the classification and nomenclature of the DNA- $\beta$ satellites of begomoviruses. Arch. Virol. 153, 763-781. https://doi. org/10.1007/s00705-007-0013-6

Briddon RW, Bull SE, Amin I, Mansoor S, Bedford ID, Rishi N, Siwatch SS, Zafar MY, Abdel-Salam AM, Markham PG (2004): Diversity of DNA 1; a satellite-like molecule associated with monopartite begomovirus-DNA $\beta$ complexes. Virology 324, 462-474. https://doi.org/10.1016/j. virol.2004.03.041 
Briddon RW, Markham PG (2000): Cotton leaf curl virus disease. Virus Res. 71, 151-159. https://doi.org/10.1016/S0168$\underline{1702(00) 00195-7}$

Cai JH, Xie K, Lin L, Qin BX, Chen BS, Meng JR, Liu YL (2010): Cotton leaf curl Multan virus newly reported to be associated with cotton leaf curl disease in China. Plant Pathol. 59, 794-795. https://doi.org/10.1111/j.13653059.2010.02266.x

Chellappan P, Vanitharani R, Fauquet CM (2004): Short interfering RNA accumulation correlates with host recovery in DNA virus-infected hosts, and gene silencing targets specific viral sequences. J. Virol. 78, 7465-7477. https:// doi.org/10.1128/JVI.78.14.7465-7477.2004

Cui X, Li G, Wang D, Hu D, Zhou X (2005): A begomovirus DNA $\beta$ encoded protein binds DNA, functions as a suppressor of RNA silencing, and targets the cell nucleus. J. Virol. 79, 10764-10775. https://doi.org/10.1128/JVI.79.16.10764$\underline{10775.2005}$

Dalakouras A, Wassenegger M (2013): Revisiting RNA-directed DNA methylation. RNA Biology 10, 453-455. https:// doi.org/10.4161/rna.23542

Doyle JJ, Doyle JL (1990): Isolation of plant DNA from fresh tissue. Focus 12, 13-15.

Frischmuth S, Frischmuth T, Jeske H (1991): Transcript mapping of abutilon mosaic virus, a geminivirus. Virology 11815, 596-604. https://doi.org/10.1016/0042-6822(91)90530-O

Guerineau F, Mullineaux P (1993): Plant transformation and expression vectors. In R. R. D. Croy (Ed.): Plant Molecular Biology Labfax. Bios Scientific Publishers, Oxford, pp. 121-147. https://doi.org/10.1016/B978-0-08-0917535.50010-X

Hanley-Bowdoin L, Bejarano ER, Robertson D, Mansoor S (2013): Geminiviruses: masters at redirecting and reprogramming plant processes. Nat. Rev. Microbiol. 11, 777-788. https://doi.org/10.1038/nrmicro3117

Hellens RP, Edwards EA, Leyland NR, Bean S, Mullineaux PM (2000): pGreen: a versatile and flexible binary Ti vector for Agrobacterium-mediated plant transformation. Plant Mol. Biol. 42, 819-832. https://doi. org/10.1023/A:1006496308160

Himber C, Dunoyer P, Moissiard G, Ritzenthaler C, Voinnet O (2003): Transitivity-dependent and -independent cell-tocell movement of RNA silencing. EMBO J. 22, 4523-4533. https://doi.org/10.1093/emboj/cdg431

Horsch RB, Fry JE, Hoffmann NL, Eichholtz D, Rogers SG, Fraley RT (1985): A simple and general method for transferring genes into plants. Science 227, 1229-1231. https://doi. org/10.1126/science.227.4691.1229

Hussain M, Mansoor S, Iram S, Zafar Y, Briddon RW (2007): The hypersensitive response to tomato leaf curl New Delhi virus nuclear shuttle protein is inhibited by transcriptional activator protein. Mol. Plant-Microbe Interact. 20, 1581-1588. https://doi.org/10.1094/MPMI-20-12-1581

Ilyas M, Amin I, Mansoor S, Briddon RW, Saeed M (2010): Challenges for transgenic resistance against geminiviruses. In Sharma P, Gaur RK, Ikegami M (Eds): Emerging Geminiviral Diseases and their Management. Nova Science Publishers Inc., New York, pp. 1-35.
Iqbal Z, Sattar MN, Kvarnheden A, Mansoor S, Briddon RW (2012): Effects of the mutation of selected genes of cotton leaf curl Kokhran virus on infectivity, symptoms and the maintenance of cotton leaf curl Multan betasatellite. Virus Res. 169, 107-116. https://doi.org/10.1016/j.virusres.2012.07.016

Iqbal Z, Sattar MN, Shafiq M (2016): CRISPR/Cas9: A tool to circumscribe cotton leaf curl disease. Front. Plant Sci. 7, 475, 1-11. https://doi.org/10.3389/fpls.2016.00475

Iqbal Z, Shafiq M, Ali I, Mansoor S, Briddon RW (2017): Maintenance of cotton leaf curl Multan betasatellite by tomato leaf curl New Delhi virus. Analysis by mutation. Front. Plant Sci. 8, 2208, 1-16. https://doi.org/10.3389/ fpls.2017.02208

Li F, Huang C, Li Z, Zhou X (2014): Suppression of RNA silencing by a plant DNA virus satellite requires a host calmodulinlike protein to repress RDR6 expression. PLoS Pathog. 10, e1003921. https://doi.org/10.1371/journal.ppat.1003921

Lin C-Y, Tsai W-S, Ku H-M, Jan F-J (2012): Evaluation of DNA fragments covering the entire genome of a monopartite begomovirus for induction of viral resistance in transgenic plants via gene silencing. Transgenic Res. 21, 231-241. https://doi.org/10.1007/s11248-011-9523-9

Mansoor S, Amin I, Iram S, Hussain M, Zafar Y, Malik KA, Briddon RW (2003): Breakdown of resistance in cotton to cotton leaf curl disease in Pakistan. Plant Pathol. 52, 784. https:// doi.org/10.1111/j.1365-3059.2003.00893.x

Mubin M, Hussain M, Briddon RW, Mansoor S (2011): Selection of target sequences as well as sequence identity determine the outcome of RNAi approach for resistance against cotton leaf curl geminivirus complex. Virol. J. 8, 122-129. https://doi.org/10.1186/1743-422X-8-122

Mubin M, Mansoor S, Hussain M, Zafar Y (2007): Silencing of AV2 gene by antisense RNA protect transgenic plants against a bipartite begomovirus Virol. J. 4, 10. https://doi. org/10.1186/1743-422X-4-10

Noris E, Lucioli A, Tavazza R, Caciagli P, Accotto GP, Tavazza M (2004): Tomato yellow leaf curl Sardinia virus can overcome transgene-mediated RNA silencing of two essential viral genes. J. Gen. Virol. 85, 1745-1749. https:// doi.org/10.1099/vir.0.79944-0

Noueiry AO, Lucas WJ, Gilbertson RL (1994): Two proteins of a plant DNA virus coordinate nuclear and plasmodesmal transport. Cell 76, 925-932. https://doi.org/10.1016/0092$\underline{8674(94) 90366-2}$

Pooggin M, Shivaprasad PV, Veluthambi K, Hohn T (2003): RNAi targeting of DNA virus in plants. Nat. Biotechnol. 21, 131-132. https://doi.org/10.1038/nbt0203-131b

Pumplin N, Voinnet O (2013): RNA silencing suppression by plant pathogens: defence, counter-defence and countercounter-defence. Nat Rev Micro 11, 745-760. https://doi. org/10.1038/nrmicro3120

Qazi J, Amin I, Mansoor S, Iqbal J, Briddon RW (2007): Contribution of the satellite encoded gene $\beta \mathrm{C} 1$ to cotton leaf curl disease symptoms. Virus Res. 128, 135-139. Rajagopalan PA, Naik A, Katturi P, Kurulekar M, Kankanallu RS, Anandalakshmi R (2012): Dominance of resistance- 
breaking cotton leaf curl Burewala virus $(\mathrm{CLCuBuV})$ in northwestern India. Arch. Virol. 157, 855-868.

Rojas MR, Jiang H, Salati R, Xoconostle-Cázares B, Sudarshana MR, Lucas WJ, Gilbertson RL (2001): Functional analysis of proteins involved in movement of the monopartite begomovirus, Tomato yellow leaf curl virus. Virology 291, 110-125. https://doi.org/10.1006/viro.2001.1194

Sambrook J, Frisch EF, Maniatis T (1989): Molecular Cloning: A Laboratory Manual. Cold Spring Harbor Laboratory Press, New York.

Sattar MN, Kvarnheden A, Saeed M, Briddon RW (2013): Cotton leaf curl disease - an emerging threat to cotton production worldwide. J. Gen. Virol. 94, 695-710. https://doi. org/10.1099/vir.0.049627-0

Shafiq M, Iqbal Z, Ali I, Abbas Q, Mansoor S, Briddon RW, Amin I (2017): Real-time quantitative PCR assay for the quantification of virus and satellites causing leaf curl disease in cotton in Pakistan. J. Virol. Methods 248, 54-60. https:// doi.org/10.1016/j.jviromet.2017.05.012

Shepherd DN, Martin DP, Thomson JA (2009): Transgenic strategies for developing crops resistant to geminiviruses. Plant Sci. 176, 1-11. https://doi.org/10.1016/j.plantsci.2008.08.011

Shukla R, Dalal S, Malathi V (2013): Suppressors of RNA silencing encoded by tomato leaf curl betasatellites. J. Biosci. 38, 45-51. https://doi.org/10.1007/s12038-012-9291-6

Vanderschuren H, Akbergenov R, Pooggin M, Hohn T, Gruissem W, Zhang P (2007a): Transgenic cassava resistance to African cassava mosaic virus is enhanced by viral DNA-A bidirectional promoter-derived siRNAs. Plant Mol. Biol. 64, 549-557. https://doi.org/10.1007/s11103-007-9175-6

Vanderschuren H, Stupak M, Fütterer J, Gruissem W, Zhang P (2007b): Engineering resistance to geminiviruses - review and perspectives. Plant Biotechnol. J. 5, 207-220. https:// doi.org/10.1111/j.1467-7652.2006.00217.x

Wang B, Li F, Huang C, Yang X, Qian Y, Xie Y, Zhou X (2014): V2 of tomato yellow leaf curl virus can suppress methylationmediated plant transcriptional gene silencing. J. Gen. Virol. 95, 225-230. https://doi.org/10.1099/vir.0.055798-0
Yadav RK, Chattopadhyay D (2011): Enhanced viral intergenic region-specific short interfering RNA sccumulation and DNA methylation correlates with resistance against a geminivirus. Mol. Plant-Microbe Interact. 24, 1189-1197. https://doi.org/10.1094/MPMI-03-11-0075

Yang X, Wang Y, Guo W, Xie Y, Xie Q, Fan L, Zhou X (2011a): Characterization of small interfering RNAs derived from the geminivirus/betasatellite complex using deep sequencing. PLoS ONE 6, e16928. https://doi.org/10.1371/journal. pone.0016928

Yang X, Xie Y, Raja P, Li S, Wolf JN, Shen Q, Bisaro DM, Zhou X (2011b): Suppression of methylation-mediated transcriptional gene silencing by $\beta \mathrm{C} 1$-SAHH protein interaction during geminivirus-betasatellite infection. PLoS Pathog. 7, Zaffalon V, Mukherjee S, Reddy V, Thompson J, Tepfer M (2012): A survey of geminiviruses and associated satellite DNAs in the cotton-growing areas of northwestern India. Arch. Virol. 157, 483-495.

Yasmeen A, Kiani S, Butt A, Rao AQ, Akram F, Ahmad A, Nasir IA, Husnain T, Mansoor S, Amin I, Aftab S, Zubair M, Tahir MN, Akhtar S, Scheffler J, Scheffler B (2016): Ampliconbased RNA interference targeting V2 gene of Cotton leaf curl Kokhran virus-Burewala strain can provide resistance in transgenic cotton plants. Mol. Biotechnol. 58, 807-820. https://doi.org/10.1007/s12033-016-9980-8

Zhou X (2013): Advances in understanding begomovirus satellites. Ann. Rev. Phytopathol. 51, 357-381. https://doi. org/10.1146/annurev-phyto-082712-102234

Zhou X, Liu Y, Robinson DJ, Harrison BD (1998): Four DNA-A variants among Pakistani isolates of cotton leaf curl virus and their affinities to DNA-A of geminivirus isolates from okra. J. Gen. Virol. 79, 915-923. https://doi. org/10.1099/0022-1317-79-4-915

Zubair M, Zaidi SSA, Shakir S, Farooq M, Amin I, Scheffler JA, Scheffler BE, Mansoor S (2017): Multiple begomoviruses found associated with cotton leaf curl disease in Pakistan in early 1990 are back in cultivated cotton. Sci. Rep. 7, 680. https://doi.org/10.1038/s41598-017-00727-2 


\title{
Supplementary information
}

\section{The antisense 5 ' end of the V2 gene confers enhanced resistance against themonopartite begomovirus cotton leaf curl Kokhran virus-Burewala strain}

\author{
I. ALI' ${ }^{1 *}$, M. KHURSHID ${ }^{1,2}$, Z. IQBAL ${ }^{1}$, M. SHAFIQ ${ }^{1}$, I. AMIN ${ }^{1}$, S. MANSOOR ${ }^{1}$, R. W. BRIDDON ${ }^{1}$ \\ ${ }^{1}$ Agricultural Biotechnology Division, National Institute for Biotechnology and Genetic Engineering, P. O. Box 577, Jhang road, \\ Faisalabad, Pakistan; ${ }^{2}$ Institute of Biochemistry and Biotechnology, University of Punjab, Lahore
}

Received March 20, 2018; revised June 28, 2018; accepted January 03, 2019

Table S1. Oligonucleotide primers used in the study

\begin{tabular}{|c|c|c|}
\hline Primer & Sequence $\left(5^{\prime}-3^{\prime}\right)^{*}$ & Predicted product size \\
\hline V2NF & AATG $\underline{\text { AAGCTTATGAGTAAGTTTTCTCTACTAACTG }}$ & \multirow{2}{*}{$94 \mathrm{bp}$} \\
\hline V2NR & CGTTGAATTCTAATGGGATCCACTGTTAAATGAGT & \\
\hline V2MF & CGGCAAGCTTATGGGCTGTCGAAGTTGAGACGGC & \multirow{2}{*}{$93 \mathrm{bp}$} \\
\hline V2MR & ATTTGAATTCTGAAATAAGGGCTAGGAATTATGT & \\
\hline $\mathrm{V} 2 \mathrm{CF}$ & TTCAAAGCTTATGGGAACATCTGGACTTCTGTAC & \multirow{2}{*}{95 bp } \\
\hline V2CR & CGTGGAATTCTAGCCATTGTCCGCGTCACCAAAG & \\
\hline PedLCVV2F & ATGTGGGATCCGTTATTGAAC & \multirow{2}{*}{$358 \mathrm{bp}$} \\
\hline PedLCVV2R & CTAGGAACATCTGGACTTCTG & \\
\hline ToLCNDV2F & GGTCGACAAACATGTGGGATCC & \multirow{2}{*}{$361 \mathrm{bp}$} \\
\hline ToLCNDV2R & CCCGGGCTTCTATACATTCTGTAC & \\
\hline CLCKV2F & GTCGACAAGTATGCGTTTGAAAAATGTG & \multirow{2}{*}{354 bp } \\
\hline CLCKV2R & GGATCCACСTTCACATCCTCTAGGAAC & \\
\hline NterS & ATGAGTAAGTTTTCTCTACTAACTG & \multirow{2}{*}{$94 \mathrm{bp}$} \\
\hline NterAS & TAATGGGATCCACTGTTAAATGAGT & \\
\hline MPorS & ATGGGCTGTCGAAGTTGAGACGGC & \multirow{2}{*}{$94 \mathrm{bp}$} \\
\hline MPorAS & TGAAATAAGGGCTAGGAATTATGT & \\
\hline CterS & ATGGGAACATCTGGACTTCTGTAC & \multirow{2}{*}{$93 \mathrm{bp}$} \\
\hline CterAS & TAGCCATTGTCCGCGTCACCAAAG & \\
\hline P35F & GACAGTGGTCCCAAAGATGGA & \multirow{2}{*}{$650 \mathrm{bp}$} \\
\hline P35R & CAGTGGAGATATCACATCAATCCA & \\
\hline IRVF & CGTGGAATTCATGTGGGATCCACTGTTAAATGAG & \multirow{2}{*}{$128 \mathrm{bp}$} \\
\hline IRVR & TTCGTCGACGAACATCTGGACTTCTGTA & \\
\hline DNAAqPCRF & CСTTTAATCATGACTGGCTT & \multirow{2}{*}{$1445 \mathrm{bp}$} \\
\hline DNAAqPCRR & CATTTCCATCCGAACATTC & \\
\hline BetaqPCRF & GATTTGACTTATATTGGGCCAATTTAAT & \multirow{2}{*}{$132 \mathrm{bp}$} \\
\hline BetaqPCRR & GATACTATCCACAAAGTCACCATCGCTAAT & \\
\hline 18s rRNAF & TCTGCCCTATCAACTTTCGATGGTA & \multirow{2}{*}{$137 \mathrm{bp}$} \\
\hline 18s rRNAR & AATTTGCGCGCCTGCTGCCTTCCTT & \\
\hline
\end{tabular}

${ }^{\star} E c o$ RI (GAATTC) and HindIII (AAGCTT) recognitions sequences used for cloning the V2 gene fragments are underlined.

\footnotetext{
* Present address: Centre of Agricultural Biochemistry and Biotechnology, University of Agriculture, Faisalabad, Pakistan. E-mail: irfan.nibge@gmail.com; phone: +92-41-9200161.
} 
Table S2. Analysis of transgenic N. benthamiana plants

\begin{tabular}{|c|c|c|c|c|c|}
\hline \multirow{3}{*}{ Construct } & \multirow{3}{*}{ Line } & \multirow{3}{*}{$\begin{array}{c}\text { Kanamycin resistance } \\
\text { (plants resistant/plants examined) } \\
\mathrm{T}_{2}\end{array}$} & \multicolumn{2}{|c|}{$\begin{array}{l}\text { PCR-mediated detection of construct } \\
\text { (plants positive/plants examined) }\end{array}$} & \multirow{3}{*}{ Transgene specific sRNA } \\
\hline & & & \multicolumn{2}{|c|}{$\mathrm{T}_{2}$} & \\
\hline & & & $35 S$ & $\mathrm{Tg}$ & \\
\hline \multirow{3}{*}{$\mathrm{BV} 2^{\mathrm{N}}$} & 1 & $6 / 7$ & $5 / 5$ & $4 / 5$ & $(-)$ \\
\hline & 2 & $5 / 5$ & $5 / 5$ & $5 / 5$ & $(+)$ \\
\hline & 3 & $7 / 7$ & $5 / 5$ & $5 / 5$ & $(-)$ \\
\hline \multirow{3}{*}{$\mathrm{BV} 2^{\mathrm{M}}$} & 1 & $5 / 5$ & $5 / 5$ & $5 / 5$ & $(-)$ \\
\hline & 2 & $6 / 6$ & $4 / 4$ & $4 / 4$ & $(+)$ \\
\hline & 3 & $5 / 5$ & $3 / 5$ & $4 / 5$ & $(-)$ \\
\hline \multirow{3}{*}{$\mathrm{BV} 2^{\mathrm{C}}$} & 1 & $5 / 5$ & $5 / 5$ & $5 / 5$ & $(-)$ \\
\hline & 2 & $4 / 4$ & $5 / 5$ & $5 / 5$ & $(-)$ \\
\hline & 3 & $5 / 5$ & $5 / 5$ & $5 / 5$ & $(+)$ \\
\hline
\end{tabular}

${ }^{*}$ The results of the detection of transgene-derived sRNAs in $\mathrm{T}_{3}$ generation plants by hybridization are given as either positive (+) or negative (-). ${ }^{8}$ Transgenic lines were examined for incorporation of the expression constructs by PCR-mediated amplification of CaMV 35S promoter sequences (35S) using primer pair P35F/P35R (Table S1) and virus sequences (Tg) using primer pairs V2NF/V2NR (for the N-terminal fragment), V2MF/V2MR (for the middle fragment) and $\mathrm{V} 2 \mathrm{CF} / \mathrm{V} 2 \mathrm{CR}$ (for the C-terminal fragment).

Table S3. Quantitative real time PCR analysis of virus/betasatellite DNA levels in infected transgenic N. benthamiana plants

\begin{tabular}{|c|c|c|c|c|c|c|c|c|c|c|c|c|}
\hline \multirow[b]{2}{*}{ Construct $^{*}$} & \multicolumn{2}{|c|}{ CLCuKoV-Bu } & \multicolumn{4}{|c|}{ CLCuKoV-Bu/CLCuMuB } & \multicolumn{2}{|c|}{ CLCuKoV } & \multicolumn{2}{|c|}{ PeLCV } & \multicolumn{2}{|c|}{ ToLCNDV } \\
\hline & $\begin{array}{c}\text { virus } \\
(\mathbf{n g} / \mu \mathrm{g})^{\#}\end{array}$ & $\mathrm{SD}^{\mathrm{s}}$ & $\begin{array}{c}\text { virus } \\
(\mathrm{ng} / \mu \mathrm{g}) \#\end{array}$ & $\mathbf{S D}^{\$}$ & $\begin{array}{c}\text { beta- } \\
\text { satellite } \\
(\mathrm{ng} / \mu \mathrm{g})^{*}\end{array}$ & $\mathrm{SD}^{\mathrm{s}}$ & $\begin{array}{c}\text { virus } \\
(\mathbf{n g} / \mu \mathrm{g})^{\#}\end{array}$ & $\mathrm{SD}^{\$}$ & $\begin{array}{c}\text { virus } \\
(\mathrm{ng} / \mu \mathrm{g})^{\#}\end{array}$ & $\mathrm{SD}^{\varsigma}$ & $\underset{(\mathrm{ng} / \mu \mathrm{g})^{\#}}{\text { virus }}$ & $\mathrm{SD}^{\mathrm{s}}$ \\
\hline NB & 0.000 & 0.000 & 0.000 & 0.000 & 0.000 & 0.000 & 0.000 & 0.000 & 0.000 & 0.000 & 0.000 & 0.000 \\
\hline INB & $0.007^{\mathrm{A}}$ & 0.001 & $0.068^{\mathrm{A}}$ & 0.004 & $0.598^{\mathrm{A}}$ & 0.040 & $0.007^{\mathrm{A}}$ & 0.001 & $0.045^{\mathrm{A}}$ & 0.004 & $0.048^{\mathrm{A}}$ & 0.004 \\
\hline $\mathrm{BV} 2^{\mathrm{N}}$ & 0.000 & 0.000 & $0.002^{\mathrm{B}}$ & 0.001 & $0.062^{\mathrm{B}}$ & 0.022 & 0.000 & 0.000 & $0.025^{\mathrm{B}}$ & 0.001 & $0.026^{\mathrm{B}}$ & 0.002 \\
\hline $\mathrm{BV} 2^{\mathrm{N}}$ & 0.000 & 0.000 & $0.002^{\mathrm{B}}$ & 0.001 & $0.062^{\mathrm{B}}$ & 0.022 & 0.000 & 0.000 & $0.023^{\mathrm{B}}$ & 0.001 & $0.025^{\mathrm{B}}$ & 0.002 \\
\hline$B V 2^{\mathrm{M}}$ & $0.001^{\mathrm{B}}$ & 0.000 & $0.045^{\mathrm{C}}$ & 0.003 & $0.105^{\mathrm{C}}$ & 0.015 & $0.005^{\mathrm{B}}$ & 0.000 & $0.014^{\mathrm{C}}$ & 0.001 & $0.009^{\mathrm{C}}$ & 0.001 \\
\hline$B V 2^{\mathrm{M}}$ & $0.001^{\mathrm{B}}$ & 0.000 & $0.053^{\mathrm{C}}$ & 0.003 & $0.114^{\mathrm{C}}$ & 0.021 & $0.005^{\mathrm{B}}$ & 0.000 & $0.016^{\mathrm{C}}$ & 0.001 & $0.010^{\mathrm{C}}$ & 0.001 \\
\hline $\mathrm{BV} 2^{\mathrm{C}}$ & $0.004^{\mathrm{C}}$ & 0.001 & $0.009^{\mathrm{D}}$ & 0.001 & $0.225^{\mathrm{D}}$ & 0.021 & $0.002^{\mathrm{C}}$ & 0.000 & $0.011^{\mathrm{D}}$ & 0.001 & $0.016^{\mathrm{D}}$ & 0.002 \\
\hline $\mathrm{BV}^{\mathrm{C}}$ & $0.004^{\mathrm{C}}$ & 0.001 & $0.010^{\mathrm{D}}$ & 0.002 & $0.293^{\mathrm{D}}$ & 0.025 & $0.002^{\mathrm{C}}$ & 0.000 & $0.012^{\mathrm{D}}$ & 0.001 & $0.017^{\mathrm{D}}$ & 0.001 \\
\hline
\end{tabular}

${ }^{*}$ The DNA samples examined were either extracted from healthy $N$. benthamiana plants (NB), virus infected $N$. benthamiana plants (INB) or transgenic

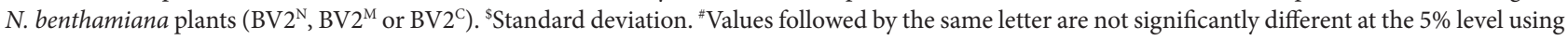
a two tailed $t$ test. 
(a)

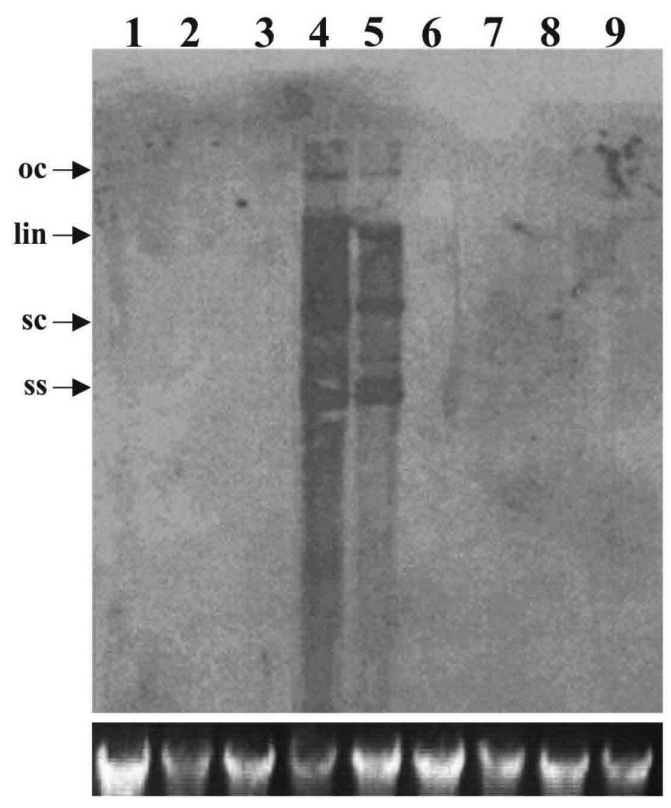

(d)

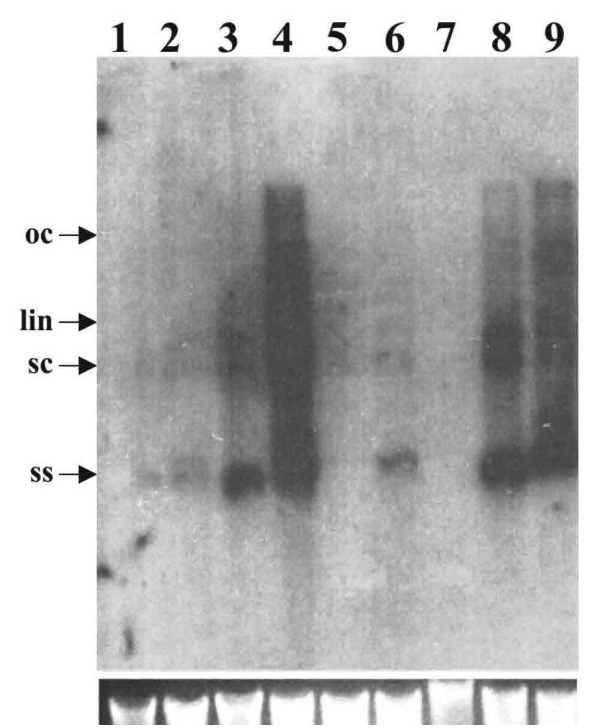

(b)

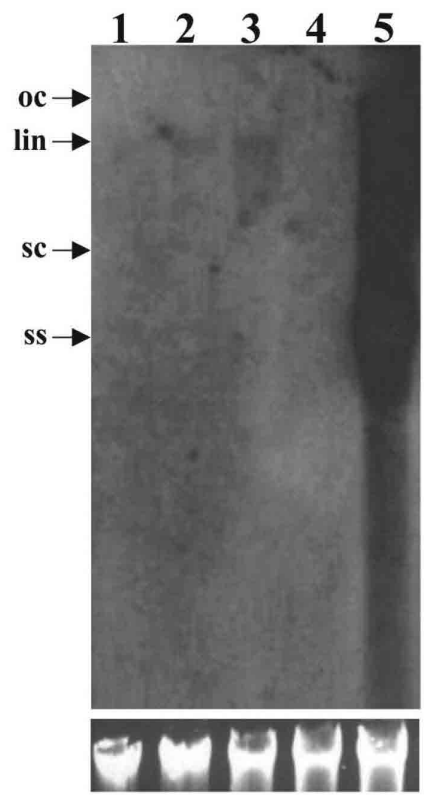

(e)

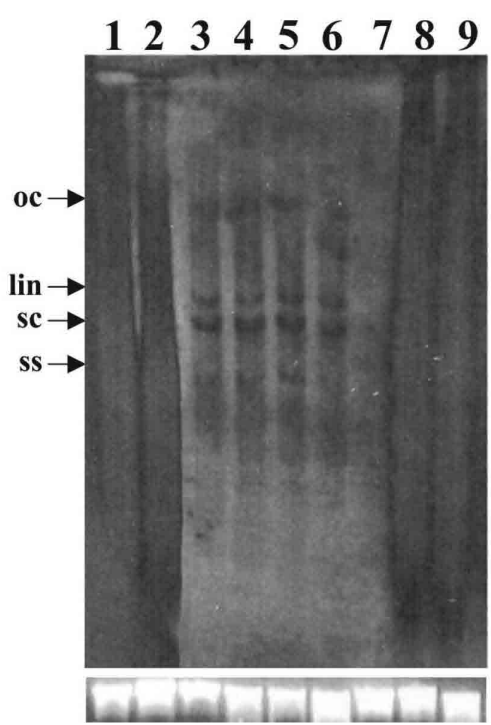

(c)

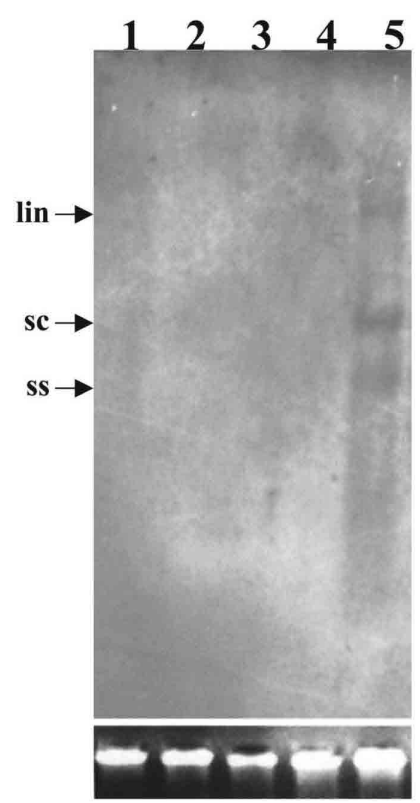

(f)

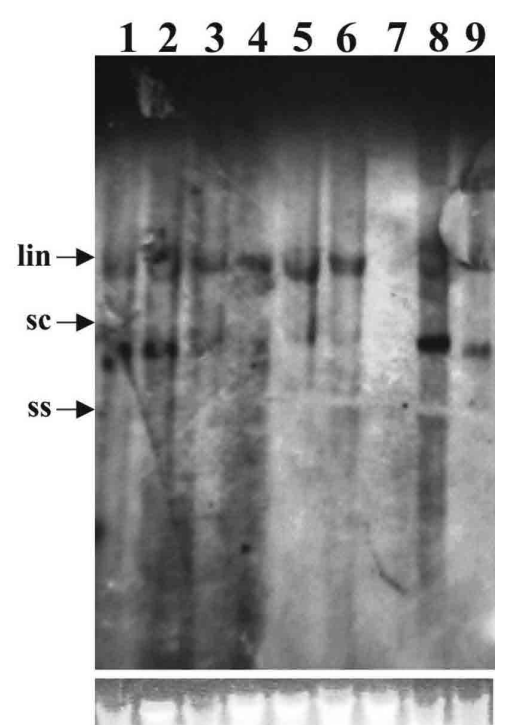

Fig. S1

Southern blot detection of begomoviruses (genomes or DNA A components) and betasatellite in inoculated $\mathrm{N}$. benthamiana plants Membranes were probed to detect the presence of CLCuKoV-Bu (a and $\mathbf{b})$, CLCuMuB (c), CLCuKoV (d), PedLCuV (e) and ToLCNDV DNA A (f). The DNA samples run on the gel were extracted from CLCuKoV-Bu (a), CLCuKoV-Bu with CLCuMuB (b and c), CLCuKoV (d), PeLCV (e) and ToLCNDV (f) inoculated transgenic plants harboring the BV2 $2^{\mathrm{N}}$ (lanes 1 and 2 in $\mathbf{a}, \mathbf{d}, \mathbf{e}, \mathbf{f}$ and lane 1 in $\mathbf{b}$ and $\mathbf{c}$ ), BV2 $2^{\mathrm{M}}$ (lanes 6 and 7 in $\mathbf{a}$, lanes 3 and 4 in $\mathbf{d}, \mathbf{e ,}, \mathbf{f}$ and lane 2 in $\mathbf{b}$ and $\mathbf{c}$ ), and BV2 ${ }^{\mathrm{C}}$ (lanes 8 and 9 in $\mathbf{a}$, lanes 5 and 6 in $\mathbf{d}$, $\mathbf{e}$ and $\mathbf{f}$ and lane 3 in $\mathbf{b}$ and $\mathbf{c}$ ) constructs. A DNA sample extracted from a non-inoculated $N$. benthamiana plant (lane 3 in $\mathbf{a}$, lane 7 in $\mathbf{d}, \mathbf{e}$ and $\mathbf{f}$ and lane 4 in $\mathbf{b}$ and $\mathbf{c}$ ) was included as a negative control. Samples from inoculated non-transgenic plants (lanes 4 and 5 in a, 8 and 9 in d, e, $\mathbf{f}$ and lane 5 in $\mathbf{b}$ and $\mathbf{c}$ ) were included as positive controls. Approximately $10 \mu \mathrm{g}$ DNA were loaded in each case. The positions of viral single-stranded (ss), super-coiled (sc), linear (lin) and open-circular (oc) DNA forms are indicated. The ethidium bromide stained genomic DNA band is shown below each blot to confirm equal loading. 


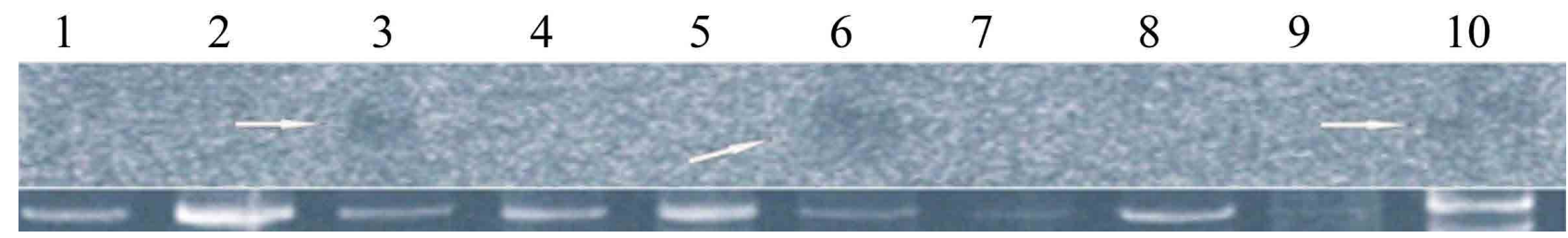

Fig. S2

\section{Detection of CLCuKoV-Bu-specific small RNAs in transgenic $N$. benthamiana plants}

Small RNA samples were extracted from a non-transgenic $N$. benthamiana plant (lane 1) and transgenic $N$. benthamiana plants (from lines 1 to 3 in each

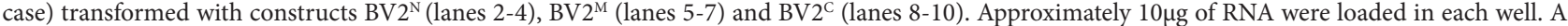
photograph of the ribosomal RNA band on the ethidium-stained acrylamide gel is shown below the blot to confirm equal loadin

(a)

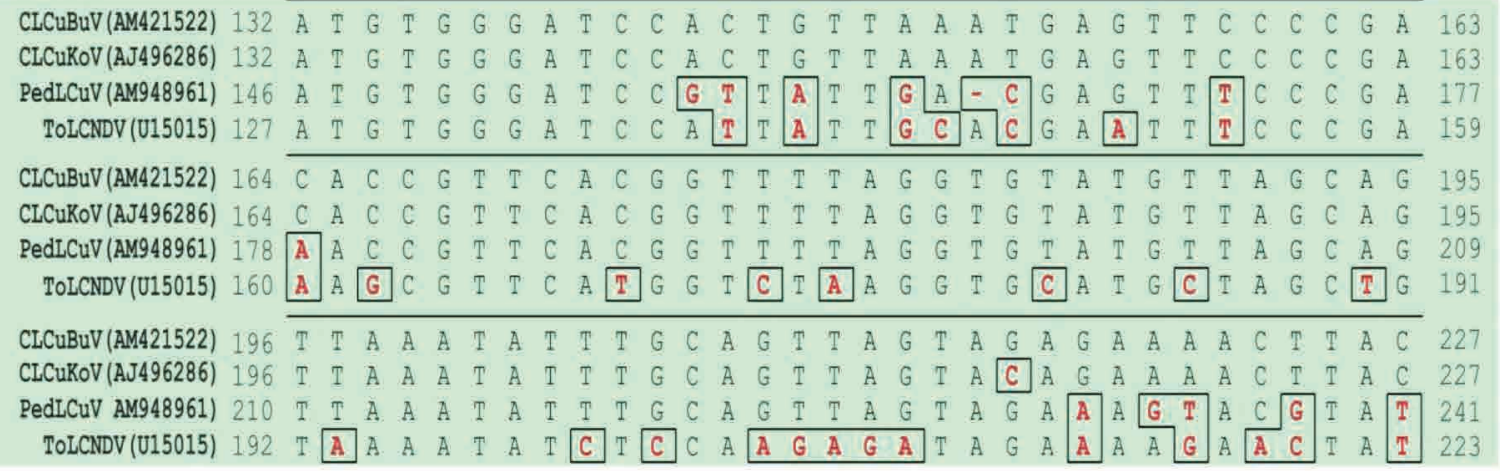

(b)

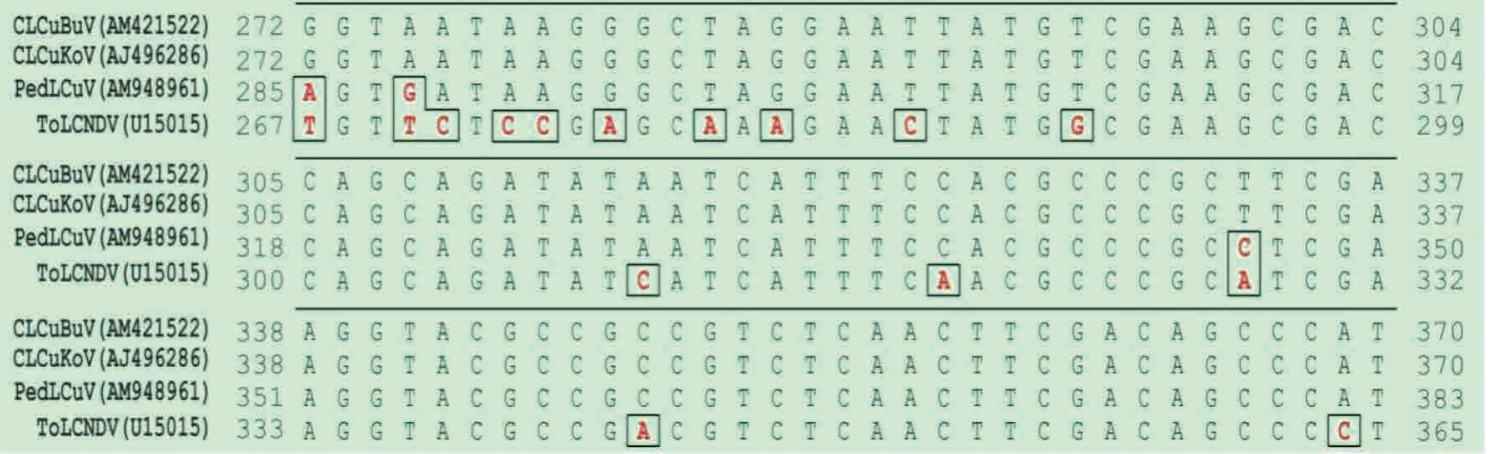

(c)

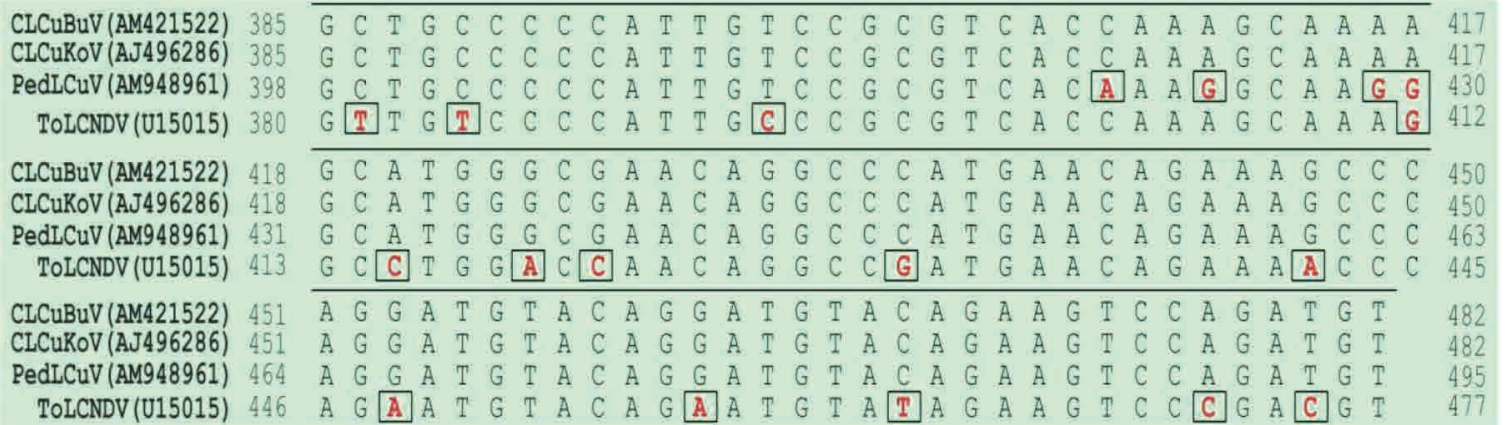

Fig. S3

Alignment of the N-terminal (a), middle portion (b) and C-terminal (c) V2 gene sequences, homologous to the cotton leaf curl Kokhran virus- $\mathrm{Bu}(\mathrm{CLCuBuV})$ fragment introduced into $N$. benthamiana, of the viruses used

Nucleotide sequences differing from cotton leaf curl Kokhran virus-Bu (top line in each case) are shown in red text and are boxed. The nucleotide coordinates of the sequences are shown in each case. 